Branislav Fábry ${ }^{*}$

\title{
MECHANIST PHILOSOPY, CONCEPT OF „OWNERSHIP“ AND LEGAL STATUS OF HUMAN BODY PARTS ${ }^{* *}$
}

\begin{abstract}
The article deals with the rise of philosophical concept of mechanism, especially in the period of Molecular Biology development and its impact on legal approach to human body. The new challenges such as cloning or human genome editing are key for the dominating concept of mechanism, however, there are some limits as well. The basic question seems to be how far we „own“ our bodies. There is also an increasing role of parents by the „enhancing" of their children. All this trends seem to be influenced by mechanism, however it creates a threat for other rights of the „enhanced“ children.
\end{abstract}

Keywords: mechanist philosophy, ownership, status of human body.

\section{Introduction}

The discussion about the status of human body parts is certainly one of the most important issues of current bioethical and legal discussions in the world. The status of the human body and the question of relationship between the human body and a human being as subject of rights are certainly important topics and not only for the contemporary Slovak debate. Do we own our bodies or are we our bodies? That is an eternal question and uneasy one. The search for an answer was strongly influenced by the rise of the mechanist philosophy during last centuries and the status of human body parts seems to be an open topic in the modern era of developing molecular biology. Especially editing of human genome seems to be a challenge for our contemporary mechanist approach to human body.

\section{Vitalism versus mechanism}

For centuries, two different and contradictory concepts of the human body and life have fought for dominance in the western philosophy - vitalism and mechanism. Vitalism claimed that the natural activities of the body are governed by the supernatural force (vital

\footnotetext{
* doc. JUDr, Associate Professor, Faculty of Law, Comenius University, Bratislava, Slovakia, e-mail: branislav.fabry@flaw.uniba.sk.

** This work was supported by the Slovak Research and Development Agency under the Contract no. APVV-18-0199.
} 
principle, life force) that gives them life. The life is not necessary a variety of physical and chemical phenomena, which are in mutual harmony, but their interaction depends on the vital principle (Gonzales-Crussi, 2008, p. 75).

The roots of vitalism go back to Aristotle, who believed that the soul revives and controls the body, and he can be considered the main representative of the school of vitalism in antiquity (Gonzales-Crussi, 2008, p. 75). Later, in the XVII century, the main representative of vitalism became G. E. Stahl. He put forward the concept of "flogiston" (vital substance), a substance able to leak when burning (Chang, 2009, pp. 770 etc). Perhaps the most famous vitalist was X. Bichat, which is known by the assertion that life is a set of functions that defy death. Bichat believed in two forms of life - animalistic and organic. The human thinking soul is related to the "anima“, vegetative life (breathing, digestion) with organic.

In the past, prevailed a rather vitalistic view that living and inanimate objects exist separately from each other, are unrelated and belong to two separate incompatible areas. However, since $19^{\text {th }}$ and especially $20^{\text {th }}$ century, the mechanism began to prevail, and its dominance was confirmed mainly by discoveries in molecular biology and genetics. The mechanism claimed that the body is an ingenious machine folded from inanimate parts. All forms of life can be perfectly explained by physical laws. Life is just a very complex physical and chemical phenomenon, although combined into one huge tangle. The soul is something layered on it. This was the basic doctrine of Cartesian dualism (Dercová, 2010).

The main representative of the mechanism and the creator of Cartesian dualism was R. Descartes (Rutheford, 2017). He and many other mechanists imagined the body as a machine. Life would be, according to them, the intricate complex of rivers with strong current substances, whose composition varies at intangible substance and that carries information throughout the body. Since this is a machine, its study requires strict observance of the laws of physics. So the school of iatrophysics was formed. To its main representatives belongs A. Borelli. His works on the volitional activity of muscles on the basis of physical laws are still valid. In addition to iatrophysics, iatrochemistry also developed, which explained the life processes at the base of chemical reactions (Campillo, 2017).

Finally, in the $19^{\text {th }}$ and $20^{\text {th }}$ century the iatrophysics and iatrochemistry disappeared to molecular biology. Genetic material in living cells in the form of deoxyribonucleic acid has been proven. The basic properties of the organism began to be addressed from the point of view of the molecular structure, and this was a great blow for vitalistic theories. Although at the moment the mechanism seems to have clearly prevailed, it leads to many open question in the field of law and ethics. The reaction to the Cartesian view of the human body was the desire to grasp a person in his entirety. However, there are other possible approaches.

One of them is phenomenology tries on the mutual unity of mind and body, with the fact that physicality is an important part of a person's personality. Normally, we do not realize our body. However, in cases such as pain, we find that with the body we create an indissoluble unity. However, phenomenology reveals hidden, characteristic features of our personal relationship to our body, thereby understanding what it means to us. We are the perceiving subject of our own body, we have a relationship to it and at the same time we can distinguish it from other objects around us. According to S. K. Toombs only through 
our body we are able to communicate with the outside world (Toombs, 2002, pp. 73-78). Phenomenology points to the body as the body of the will, just by using it we make impact to the outside world, only through fact that we perceive and experience the outside world (Kazanjian, n.d.). The body of each person has its own peculiarities (voice, movements, etc.), on the basis of which it differs from other individuals. It is by this that we perceive ourselves and create a specific relationship for ourselves and our body. We create and form our own identity. Based on our bodily features and peculiarities, we are perceived by other individuals, we are an object for them.

\section{Limits of mechanist approach and status of human body}

As mentioned, the Cartesian approach to the human body represented the innovative attitude of the modern era. From the ethical point of view, it is important to state that a person „owns" his or her body in some way, which, however, cannot be equated with the legal concept of property ownership. It is for this phenomenological point of view, the person's reference to his or her body, the idea of giving a part of it seems unacceptable. Similarly, the idea of considering our body as goods is even less acceptable, since it is incompatible with our dignity.

The human body can be defined from different points of view. From a medical point of view, this is a coherent set of organs or a substance formed by cells and intercellular matter. From a chemical point of view, it consists of water, fats, proteins and carbohydrates. According to some opinions, the chemically calculated value of the human body was at the beginning of $21^{\text {st }}$ century only 68 cents (Hildmann, 2010, p. 15). However, this does not tell us anything about the integrity of the human organism. At present, it can be said that the human body is approached from two points of view. The first is that our perception of the human body is different than the perception of other objects in the surrounding world. We choose a different way of dealing with it than with surrounding objects. The second attitude is characterized by subjective perception of our body through which we are in touch with the outside world, we perceive it and deal with it. In addition, it is also necessary to discuss whether we are truly owners of our body and our organs or tissues, as the libertarians in particular justify (Šuster, 2008, pp. 1-2).

Despite the fact that in the Slovakia prevails rather the opinion on the relations to the human body through the personal rights (Fábry, 2014) there are strong arguments for the position originating from mechanist idea of human as a machine. In most legal systems, the concept of a person also differs from the concept of human. However, the discussion on legal status of a part of the human body does not solve this at all. There are opinions that the human body is an object of sine domine and extra commercio (Štěpán, 1989, p. 348). The previous definition might be considered as vague, since it does not contain an answer to question what kind of object it is. Because if the human body is the object sui generis, we must also provide it with sui generis legislation.

Some authors from the inapplicability of specific types of legal relationships to the human body (in particular the impossibility of purchase) derived that in case of human 
body and its parts, human body has to be considered as a separate kind of object. However, the question also arises as to how impossible are the sale and purchase of the human body parts. An obstacle seems to be understanding of concept of a thing. Of course, some parts of the human body are an object of legal relations (Fábry, 2014). What are they for objects? Even the laws are ambiguous in this matter. Even the boundaries of notion "right of things" are quite difficult to determine (Mlkvá Illyová \& Dufalová, 2019).

The human body parts are often seen as an object of legal relations and sometimes as a thing, although certain types of relationship are excluded. If we understood the human body and its components as things, it would be fairly well definable. However, for the concept of parts of the human body, the concept of "thing" would then be useful. Despite the fact that proclaiming human body parts as things, many legal relations would become simpler, the notion of the integrity of Man still prevails. It must be mentioned that there are prohibitions on "inhuman treatment" and "torture" (even with consent), which undoubtedly include the interventions into the human body. So, although, on the one hand, the concept of the thing could at least somewhat contribute to the definition of the legal nature of the human body, on the other hand, the view of the human body as the thing does not reflect the importance of categories like human dignity (Fábry, 2014).

\section{Human genome as a new challenge}

The contemporary bioethical topics are one of the reasons, why the philosophy of property rights in human body parts meets its ideological frontiers. The human genome will be considered in categories like "heritage" and the disposition of patient will be described in terms like "testament“ (e. g. testamento biologico). Using this terminology is a basis for extension of property institutions, because notions like "testament“ the majority interprets like some property institution. What should we mean as to using the notion: "human genome as a common heritage"? Should it be considered as the common property of all mankind? Has every form of cloning impact on the rights of others?

Body parts transferable in a market are another difficult problem of the contemporary philosophy. „Body parts“ include any organs, tissues, cells, or genetic material on the or within the human body, or removed from it, except for some waste products. There is no easy transition from the mere existence of a market in the body parts to a sound objection in terms of commodities and human dignity. If we consider European idea of human dignity as a central one, there are several arguments against property rights in human body parts. Dignity is an unconditioned and incomparable value. Entities with dignity differ sharply from entities that have a price on the market. If human beings had property rights in body parts and exercised those rights, they would treat parts of their bodies in ways that conflict with their dignity (Fábry, 2005, pp. 371-372).

A year ago, an event took place in the field of genetics, which the scientists considered as a similar act to a fundamental breakthrough in evolution. Man took over his own evolution, began to "Play God". The case divided the world's scientific community and led to passionate debates not only among biologists, but mainly among the lawyers. It is 
not so much a medical problem, but mainly legal and ethical, where the abuse of a method can lead to far-reaching negative consequences (Fábry, 2005, pp. 374-375).

A few months ago, children were born in China, twins, whose genome was edited by Chinese scientist He, who was utilizing the method of CRISP/Cas9. Two girls were born, one of which could not get sick of AIDS infection, whereas the second child's outcome was not so unique. In other words, Dr. He prepared a kind of "genetic vaccine". This major case, which triggered a wave of disapproval, was that these changes will also inherit in subsequent generations (Sýkora, 2019, p. 512). Genetic manipulations carried out so far in the world have always ended with the death of an individual and were not transferred to the offspring.

Our approach to human body has changed with that step. Once the method is perfected, the "improvement" of the genome is conducted according to the parents' wishes. But what do we want to improve? Will the individual be satisfied with the "improvement" of human body prepared by the parents for him or her? Did he or she not have human body parts that he or she would like? The child should have an open future. Mechanist approach makes possible that a child will be born as an attempt by his parents, but the man has greater freedom if he or she „owns" a genetic mix than a pre-determined genetic assembly.

\section{References}

Chang, K. M. 2009. Motustonicus: Georg Ernst Stahl's Formulation of Tonic Motion and Early Medical Though. Bulletin of History of Medicine, 78(4), pp. 767-803.

Fábry, B. 2005. Nové biotechnologické výzvy hodnote ludskej dôstojnosti. Právny obzor, 88(4), pp. 370-379.

Gonzales-Crussi, F. 2008. Medicína. Stručné dejiny. Bratislava: Slovart.

Hildmann, Ph. W. 2010. 68 Cents oder die ethische Leitkategorie der Menschenwürde?. In: H. Badura (ed.). Der Wert des menschlichen Lebens im 21. Jahrhundert. Oder zu den Grenzen der menschlichen Verfugungsmacht. Krems an der Donau: EALIZ, pp. 15-16.

Sýkora, P. 2019. K posthumánnemu človeku prostredníctvom editovania génomv pre kognitívne schopnosti. Filozofia, 74(7), pp. 511-529.

Štěpán, J. 1989. Právo a moderní lékařství. Praha: Panorama.

Šuster, M. 2008. Rothbardova teorie smlouvy II: „scizitelné“ a „nescizitelné“ statky. Terra Libera, 9, pp. 1-4.

Toombs, S. K. 2002. What does it means to be somebody? Phenomenological Reflections and Ethical Quandaries. In: M.J Cherry (ed). Persons and their Bodies. Rights, Reposnsibilities, Relationships. Dordrecht: Springer, pp. 73-94.

\section{Website references}

Campillo, P. 2017. Giovanni Alphonso Borelli: de motu animaliu, an iatromatematics and mechanical understanding of human body and health. Available at: https:// hekint.org/2017/01/22/giovanni-alfonso-borelli-de-motu-animalium-an- 
iatromathematic-and-mechanical-understanding-of-the-body-and-health/, (last visited 15 November 2019).

Dercová, M. 2010. Ako Descartes ponechal telo na pospas prírodným vedám. Ostium Internetový časopis pre humanitné vedy, 6(4). Available at: http://ostium.sk/language/sk/akodescartes-ponechal-telo-napospas-prirodnym-vedam/, (last visited 15 November 2019).

Fábry, B. 2014. Človek, ludské telo a jeho prívny status. Projustice Vedecko-odborný recenzovaný časopis pre právo a spravodlivos. Available at: https://www.projustice. sk/teoria-prava/clovek-ludske-telo-a-jeho-pravny-status, last visited 15 November 2019.

Mlkvá Illyová,Z. \&Dufalová, L. 2019. Pojmová hranica medzi vecnými právami azáväzkami. Projustice Vedecko-odborný recenzovaný časopis pre právo a spravodlivos. Available at: https://www.projustice.sk/obcianske-pravo/pojmova-hranica-medzi-vecnymipravami-a-zavazkami, (last visited 15 November 2019).

Kazanjian, M.M. n.d. Ethics and Fenomenology. Available at: https://www.iep.utm.edu/ eth-phen/, (last visited 15 November 2019).

Rutheford, D. 2017. Descartes' Ethics. Available at: https://plato.stanford.edu/entries/ descartes-ethics/, (last visited 15 November 2019).

\section{Dr Branislav Fábry}

Docent, Pravni fakultet, Comenius univerzitet, Bratislava, Slovačka e-mail: branislav.fabry@flaw.uniba.sk

\section{MEHANISTIČKA FILOZOFIJA, KONCEPT “VLASNIŠTVA” I PRAVNI STATUS DELOVA LJUDSKOG TELA}

\section{Sažetak}

Članak se bavi pitanjem uspona filozofskog koncepta mehanizma, posebno u periodu razvoja molekularne biologije i njenog uticaja na pravni pristup ljudskom telu. Novi izazovi kao što su kloniranje ili izmena ljudskog genoma su ključni za dominantni koncept mehanizma, ali postoje i neka ograničenja. Osnovno pitanje je, čini se, u kojoj meri mi „posedujemo“ svoja tela. Takođe, javlja se pojačana uloga roditelja u „poboljšanju“ svoje dece. Čini se da na sve ove trendove utiče mehanizam, međutim, to rađa pretnju za druga prava „poboljšane“ dece.

Ključne reči: mehanistička filozofija, vlasništvo, status ljudskog tela.

Article history:

Received: 15 November 2019 Accepted: 27 January 2020 